\title{
Rapid Population Growth as Foremost Cause of Land Degradation in Ethiopia: A Review
}

\author{
Gebre Gidey $^{1 *}$ Gebrekidan Goitom ${ }^{2}$ \\ 1. Department of Natural Resource Management, Dambi Dollo University, Dambi Dollo, Ethiopia \\ 2. Aksum Agricultural Research Center, Aksum, Ethiopia
}

\begin{abstract}
Ethiopia is the second most populous country in Sub-Saharan Africa countries. The rapid population growth in country leads to land degradation; it includes soil degradation, vegetation degradation and water degradation, and natural resources degradation as whole. Diverse scholars indicated, decreasing tendency of forest cover in Ethiopia over time with the population increment. In Ethiopia, the high population growth leads to soil erosion and soil fertility loss; it accelerates soil erosion due to foot path, overgrazing and others, which is meanly estimated 12 tons/ ha/ yr. and, People are using animal dung and crop residue for household fuel rather than being added to the soil to improve soil fertility, which leads to soil quality declination. And, the population pressure leads the water courses to dry up, reduced the volumes of surface water, depletion of aquifers and pollution. If this rapid population growth of Ethiopia continues like the current situation, the land degradation problem is likely to be even more challengeable in the future. Therefore, this paper aims to explore rapid population growth as foremost cause land degradation in Ethiopia by taking typical evidence from different parts of the country and to suggest solutions.
\end{abstract}

Keywords: Rapid Population Growth, Foremost Cause, Land Degradation

DOI: $10.7176 / \mathrm{JEES} / 11-8-02$

Publication date:August $31^{\text {st }} 2021$

\section{Introduction}

Sub-Saharan African countries are characterized by very high rates of population growth, with average annual rate of 2.8 percent (Teklu 2016).Ethiopia is the second most populous country in Sub-Saharan Africa with a growth rate of 2.73 percent between 2000- 2005 (CSA 2008). This rapid population growth in the country is leading to land degradation (Teklu 2016).

Land degradation is a temporary or permanent decline in the productive capacity of the land (Paulos 2001). It includes soil degradation, vegetation degradation and water degradation, and natural resources degradation as whole (Hurni et al. 2010). It is a major global issue and international agenda for 21 st century (Temesgen et al. 2014a). Many studies suggest that 5 to 10 million hectares global are being misused annually resulting in degradation; if this tendency continues, 1.4 to 2.8 percent of total agricultural, pasture, and forestland will have been lost by 2020 (Temesgen et al. 2014b).

Ethiopia is one of the well-gifted countries in terms of land resources (Gete et al. 2006). However, land degradation has been going on for centuries (Hurni et al. 2010). The foremost cause of land degradation in Ethiopia is rapid population growth, which plays a significant role in rushing land degradation by deforestation, soil loss and eco- system degradation as general (Girma 2001). Because, as over $80 \%$ of the population of the country derives their livelihood from agriculture (Bekele and Holden 1998).

If this rapid population growth continues, the land degradation problem is likely to be even more challengeable in the future (Berry 2003). The concern of land resources sustainability and causes for the land resources degradation interlinks with the population growth. Therefore, this paper aims to explore rapid population growth as foremost cause land degradation in Ethiopia by taking typical evidence from different parts of the country and to suggest solutions.

\section{Population growth and land degradation in Ethiopia}

\subsection{The rapid human population growth}

In Ethiopia, the first national population and housing census were conducted in 1984. Based on that census, the Central Statistical Authority (CSA) has reassembled the historical outlook of the population from 1900 to 1985 (CSA 1985). Accordingly, the population of the country was projected to be 11.8 million at the start of the 20th period with growth rate of 0.2 percent per year. In 1950, the population size had enlarged to more than 19 million and its growth rate had grasped to 2.1percent per year (CSA 1985).

The mass of Ethiopian population was 40 million in 1984(CSA 1985). This number augmented to 54 million in 1994 and advance to 73.7 million in 2007(CSA 1994; 2007). And, according to the Inter-Censual Population Survey (ICPS) of 2012 and 2017 the population size had reached 84.2 and 99.3 million respectively (Figure 1).This rapid growth of population size and growth rate is the outcome of a shrill decline in mortality which was brought by the fruitful malaria and smallpox extermination programs of the 1950's and 1960's (Belay 
1995).

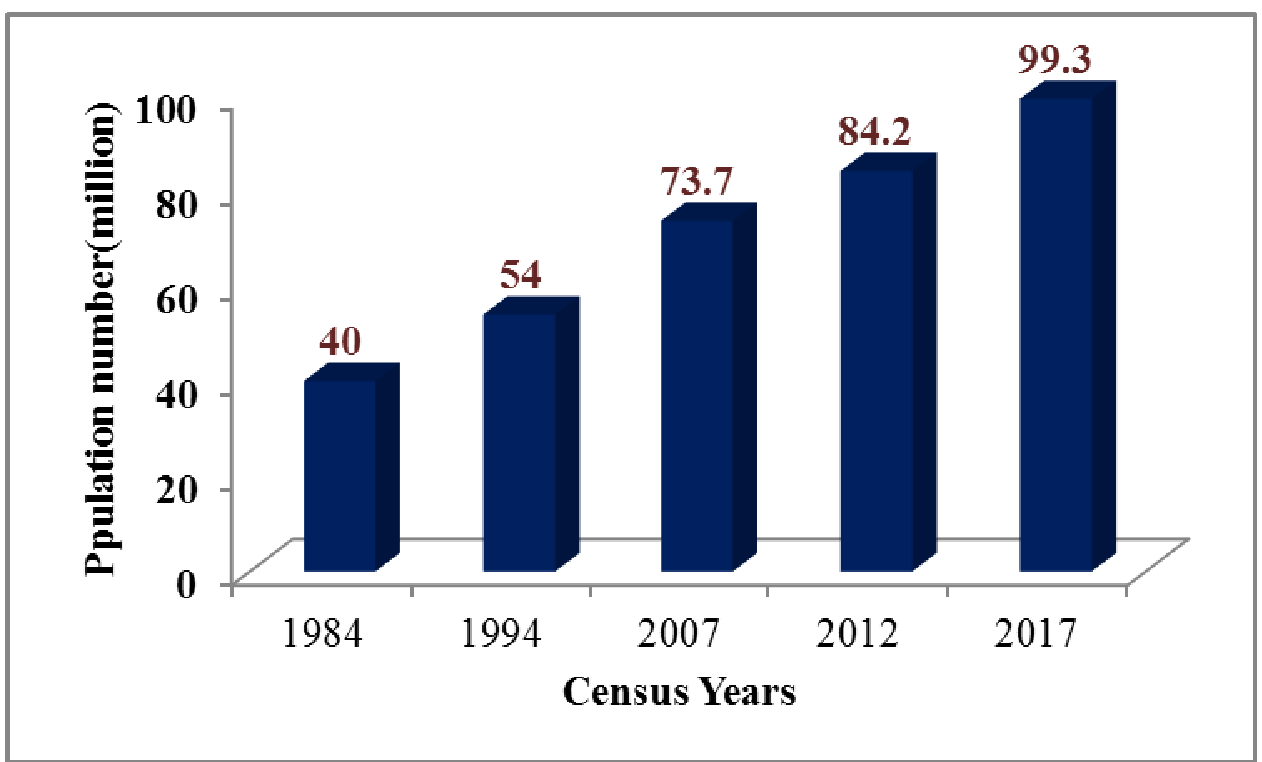

Figure1: Population growth trend in Ethiopia (Source: CSA: 1984, 1994 and 2007 census reports and ICPS of the 2012 and2017)

\subsection{Population growth nexus land degradation}

The relationship between population growth and land degradation has been a matter of argument for eras (Bekele and Stein 2003).The debate has been between those who consider population growth as the main offending factor affecting the environment, and those who have shown that population growth does not always result in land degradation (Teklu 2016).

For example, studies by Amara et al. (2011) in Eastern of Wollo (Ethiopia) and Munro et al. (2008) in Tigray highlands revealed that vegetation cover enhanced through rehabilitation by the community efforts. While, Muluneh (2003) conveyed that population growth in west Gurage (Ethiopia) is both a cause of land degradation in the practice of soil erosion and an issue for environmental enrichment in the form of conservation activities.

There are studies which stated that population growth was the original cause for land degradation in Ethiopia. For instance, Paulos (2001) discussed that the rapid growing population of Ethiopia was playing major role in Speeding up land degradation in a manner that due to growing population injured land by deforestation and overgrazing. Likewise, Fitsum et al. (1999) argued that the foremost causes of land degradation in Ethiopian are occasioned from the rising population which is displayed in positions of overgrazing, deforestation and using crop residues and dung for fuel. Berry (2003) also stated that the damage of land resource productivity in Ethiopia is due to the constant population growth.

Similar to the above point of views, Desta et al. (2000) maintained that the severe land degradation problems in the Ethiopian highlands are originating from the loads of the rapid growing human populations.

Tilahun et al. (2001) also argued that deteriorating vegetative cover and amplified levels of farming on steep slopes in Ethiopian highlands is linked with high population growth. Similarly, Temesgen et al. (2014a) reported that rapid population growth was the major powerful forces for the enlargement of cultivated lands on the forest area in Dera District (Ethiopia).

Typically, studies at large scales and long term have shown that rapid population growth has enormously major cause of land degradation (Lambin et al. 2003). Generally, the rapid population growth in Ethiopia made the land to be $9.24 \%$ very high degraded, $17.44 \%$ high degraded and $24.83 \%$ medium degraded of the total coverage of the country (Hurni et al. 2010) (Figure 2). 


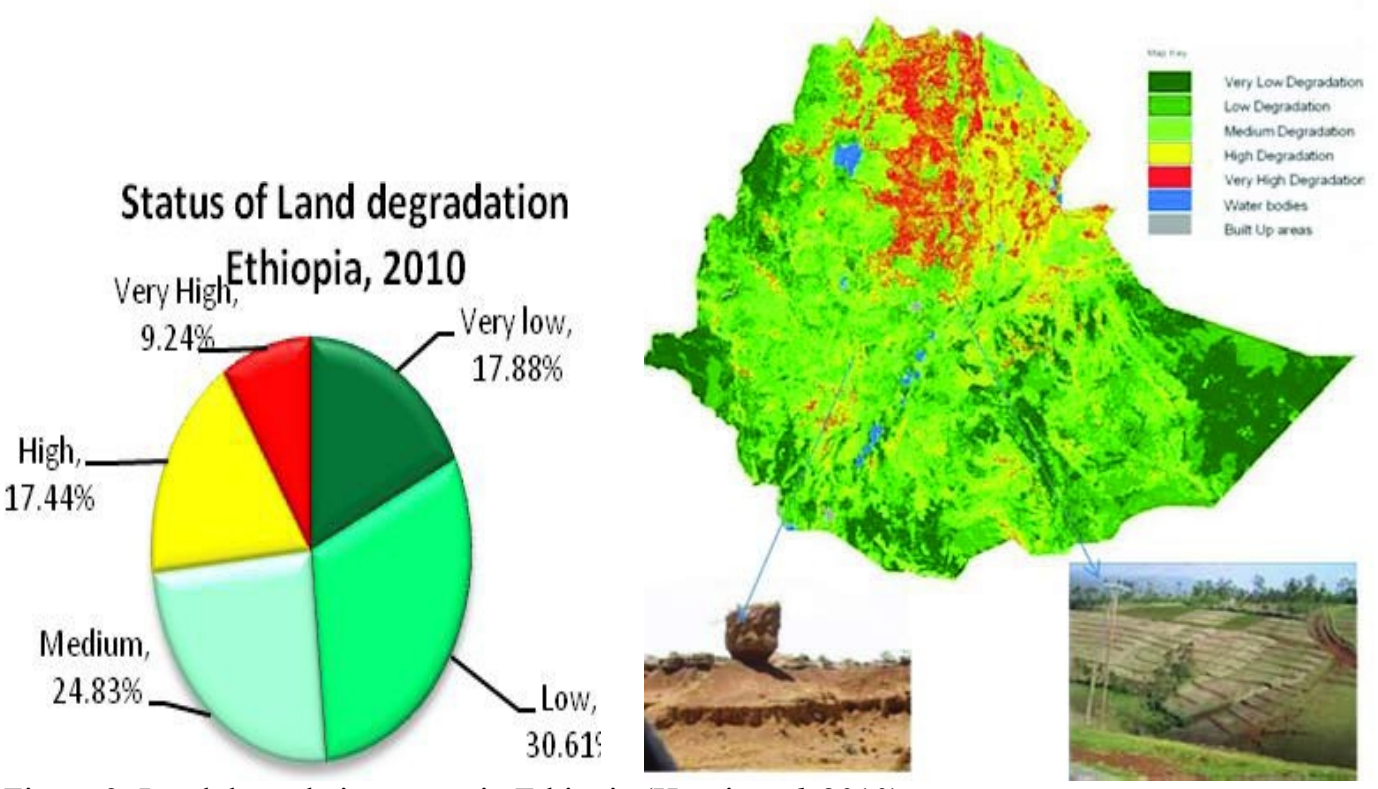

Figure 2: Land degradation status in Ethiopia (Hurni et al. 2010)

\section{Exploring land degradation forms due to population growth in Ethiopia}

Land degradation takes place in the forms of vegetation degradation, soil degradation and water degradation (Temesgen 2015). In Ethiopia, the dependence of the rapid population growth on unmannerly types of existence agriculture and natural resources use are the key reason for the those land degradation forms(forest, soil and water degradations) (Gebreyesus and Kirubel 2009).

\subsection{Vegetation degradation}

Vegetation degradation represents decrease of plant species in biomass, species diversity, or in value in terms of the nutrition (George 2002).Population growth is most factoring that reason to tropical deforestation (Geist and Lambin 2002). Population growth and poverty interrelate with a congregation of daily human consumption factors, which are fuel wood, timber and agricultural products to result land-cover change (Lambin et al. 2003). Similarly to the other tropical countries, the rapid population growth in Ethiopia raises the forest resources consumption (Gurmessa 2015).

Diverse scholars indicated, decreasing tendency of forest cover in Ethiopia over time (Gurmessa 2015). In $1960 \mathrm{~s}$, the forest coverage of the country was about 37\% (Brieten 1961). MoA (1984) also estimated that at the start of 20th century it was about $35.4 \%$, and it was reduced to $15 \%$ in 1955 (IUCN,1955), and then the country's current forest coverage to be less than 5\% (Gurmessa 2015). Likewise, different authors estimated the annual rate of deforestation in Ethiopia. For instance, McKee (2007) estimated that around 12,000 hectare deforestation rate (Table 1) in the years of 2000 and 2005.Similariy, the annual rate of deforestation in the country was estimated by Gete (2002) to be 80,000 to 200,000 hectares, and Hussein (2006) also estimated 150,000 to 200,000 hectares per annum.

Table 1: Deforestation rate of, 2000 and 2005 in Ethiopia (McKee 2007)

\begin{tabular}{llc}
\hline & \multicolumn{2}{c}{ Area in hectare } \\
\hline $\begin{array}{l}\text { Vegetation } \\
\text { Type }\end{array}$ & 2000 & 2005 \\
\hline Forest & $3,651,935$ & $3,337,988$ \\
Woodland & $10,049,079$ & $9,632,616$ \\
Shrub land & $46,297,530$ & $46,297,530$ \\
Other land & $53,169,093$ & $53,899,277$ \\
Plantation & 509,422 & 509,422 \\
\hline Total & $\mathbf{1 1 3 , 6 7 9 , 0 5 9}$ & $\mathbf{1 1 3 , 6 7 8 , 8 3 8}$ \\
\hline
\end{tabular}

This high annual deforestation area is due to the rapid population growth in the country, which leads to growing demand for more agricultural land, fuel wood, construction material and other forest products (Gete 2002) (Figure 3) 


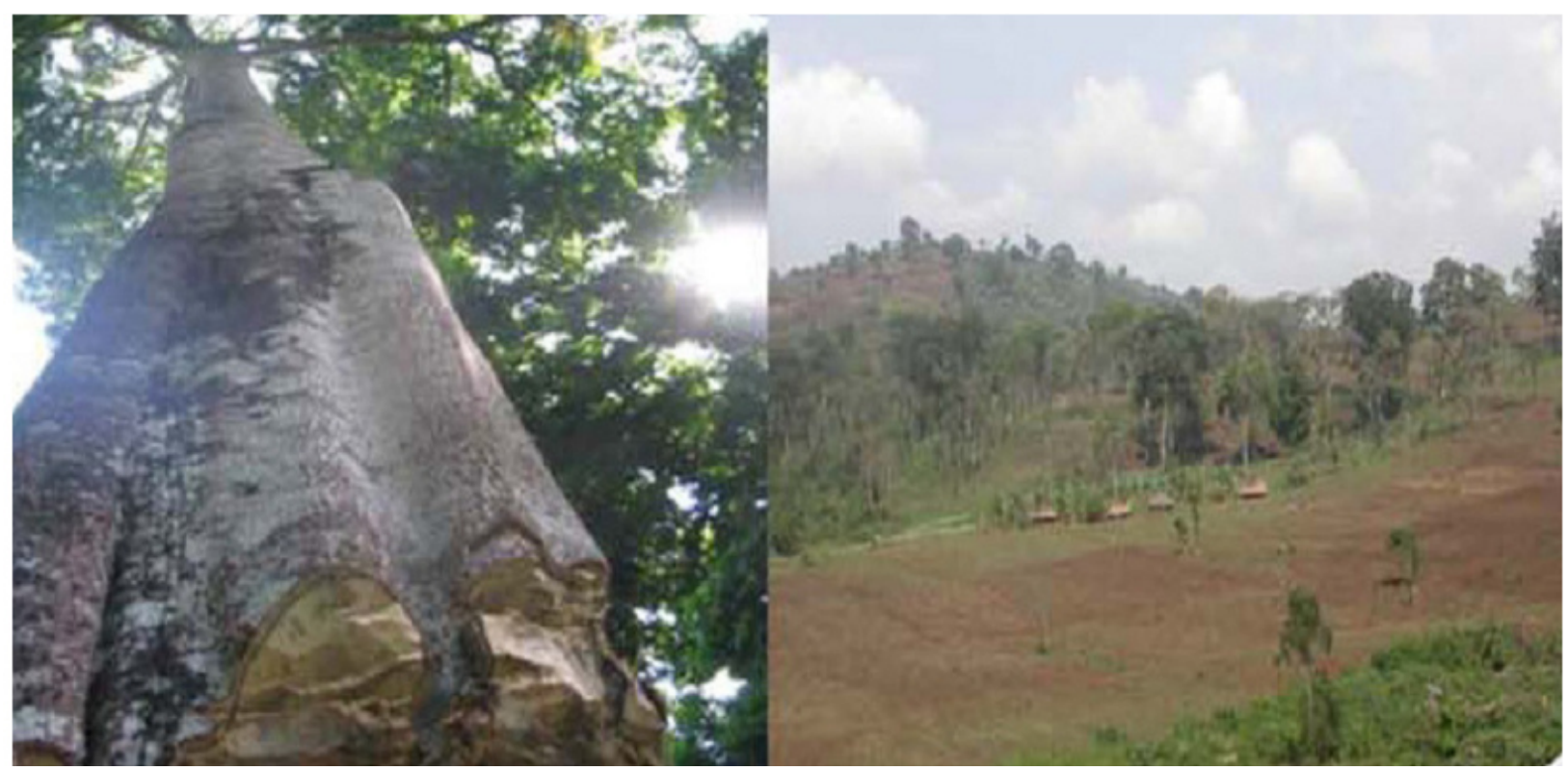

Figure 3: Illegal logging for construction (Left side) and agricultural expansion (Right side) in moist mountain forest of Ethiopia (Gurmessa 2015).

\subsection{Soil degradation}

Soil degradation indicates to the deterioration in soil qualities and quantity which includes soil erosion, low organic matter of the soil, loss of soil structure, and salinization and soil acidity problems(Wall et al. 2003). Ethiopia is one of the most severe soils degraded country in the world (Temesgen, 2015). Soil degradation in the form of soil erosion and soil fertility loss are the severe encounters in the country (Paulos 2001).

\subsubsection{Soil erosion}

Soil erosion refers to wearing a way of soil from one point on the earth surface to be deposited elsewhere by anthropogenic agents or natural factors (Mitiku et al. 2006).

In Ethiopia, the condensed reliance of growing population on a rigorous kind of agriculture with traditional approaches of invention has superior influence for soil erosion (Temesgen 2015). The population has increased very rapidly on the restricted land and each parcel of land is placed into farming, to produce food without proper management and later which outcomes soil erosion (Temesgen et al. 2014a).

Soil erosion is taking place in all corner of the country, but in northern and central highlands are highly severed, due to the effect of high population on the land that are steep and mountainous (Paulos 2001). Some highland areas of the country, which speedily occurs soil erosion are Tigray highlands, Amhara region, Hararge highlands, North and East Shewa, and Wollega and Arsi Zone (Bezuayehu et al. 2002). FAO (1986) stated that, in the mid of1980's 27 million hectare, 14 million hectare and above 2 million hectare of the highland area of Ethiopia were moderate eroded, highly eroded and very highly eroded respectively. Amhara region one of the Ethiopian highlands, soil erosion arrays 9 to 300 tons/ha/ year. Of the total area of the region,30\%, 31\%, 29\% and $10 \%$, of the region practices slight, moderate, high and very high erosion risk, respectively (Temesgen 2015) (Table 2).

Table 2: Estimated soil erosion risk classes in Amhara Region, Ethiopia (Temesgen 2015)

\begin{tabular}{lllc}
\hline Erosion classes & Range of soil loss rate (t/ha/Year) & \multicolumn{2}{c}{ Area coverage } \\
\cline { 3 - 4 } & & ha(x 10 $\left.\mathbf{~}^{\mathbf{3}}\right)$ & Percentage (\%) \\
\hline Slight & $0-15$ & 5020 & 30 \\
Moderate & $16-50$ & 5284 & 31 \\
High & $51-200$ & 4796 & 29 \\
Very high & $>200$ & 16660 & 10 \\
Total & $\mathbf{9 - 3 0 0}$ & $\mathbf{1 6 , 7 6 0}$ & $\mathbf{1 0 0}$ \\
\hline
\end{tabular}

The mean yearly rate of soil erosion in country is expected to be 12 tons/ha/yr., and it can radically outstrip this on steep slopes with soil loss 300 tons/ha/year (USAID CRSPT 2000).Of which, the 1.5 billon tons annual soil loss from Ethiopia is due to population growth (Muluneh, 2003).Population growth accelerates soil erosion due to foot path, overgrazing (Mitiku et al. 2006) (Figure 4) and cultivating steep lands (Bezuayehu et al. 2002). 


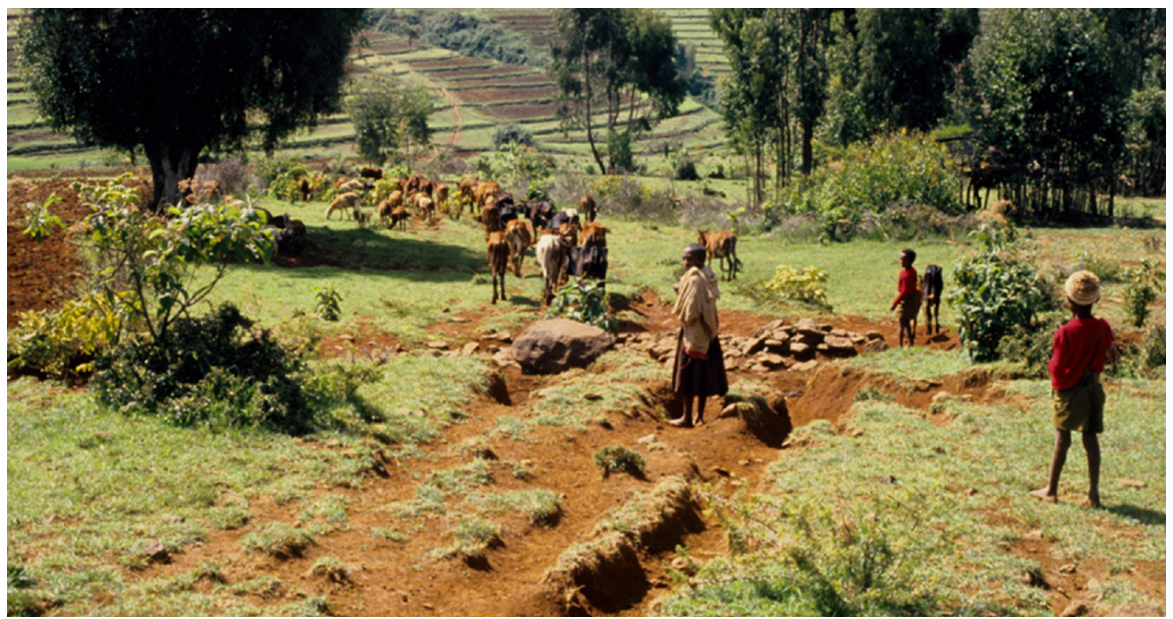

Figure 4: Livestock grazing and foot path accelerating soil erosion in Ethiopia (Mitiku et al. 2006)

\subsubsection{Soil fertility declination}

Escalation of agriculture in Sub-Saharan Africa without adding of plant nutrients has caused in wide nutrient running down and subsequent soil fertility declination (Breman and Swift 1997). In Ethiopia, the high population growth and the subsequent land-use intensity causing higher nutrient disturbance through crop removal (Drechs et al. 2001).Similarly, Fantaw (2007) stated that firewood and forest products are scares in Ethiopia due to deforestation. As a result, people are using animal dung and crop residue for household fuel rather than being added to the soil to improve soil fertility, which leads to soil quality declination. Likewise, study in Southeastern highlands of Ethiopia indicated that deforestation and their following change into farmland reduces the soil carbon content (Fantaw 2007).

Alike, the impression of population change on landholder size in Tigray region has led to descent in practice of fallowing which consequences reduce soil nutrients (Corbeels et al. 2002). Correspondingly, study by Tilahun et al. (2001) indicated that burden from the growing population leads, the farmers to cultivate marginal lands, and withdraw fallow. Similarly, Mitiku et al. (2003) reported that the soil nutrients in Tigray region are very deficient, which are $94 \%$ of the land had very low level organic carbon, $21 \%$ had very low levels of nitrogen content and 98\% low phosphorus content. Similarly, Hailu (2010) estimated $1605 \mathrm{~kg} \cdot \mathrm{ha}^{-1}, 60 \mathrm{~kg} \cdot \mathrm{ha}^{-1}$ and $590 \mathrm{~kg} \mathrm{ha}^{-1}$ for nitrogen $(\mathrm{N})$, Phosphorus (P), and potassium (K) stock at plough layer in Tahtay Maichew (Table3). This showed that the soils are attainment the lowest restrictions of productivity (World Bank 2007).

Table 3.Estimated NPK $\left(\mathrm{kg} \mathrm{ha}^{-1}\right)$ in Tahtay Maichew, Northern Ethiopia (Hailu 2010)

\begin{tabular}{llll}
\hline Soil depth $(\mathrm{cm})$ & $\mathrm{N}$ & $\mathrm{P}$ & $\mathrm{K}$ \\
\hline Plough layer(0-20) & 1605 & 60 & 590 \\
\hline Root zone(0-165) & 12030 & 600 & 3330 \\
\hline
\end{tabular}

\subsection{Water degradation}

Water degradation refers the declines of water quality and quantity (Temesgen 2015). Human actions lead the water to degraded (Owa 2013). In Ethiopia, the high population pressure leads the water courses to dry up, reduced the volumes of surface water, depletion of aquifers and pollution (Berry 2003). Teklu (2016) stated that, the application of chemical fertilizers and insecticides by high population of Ethiopia lead surface and ground contamination.

In Ethiopia, freshwater has deteriorated by pollutants, due to anthropogenic activities like urbanization, industrialization and agricultural practices (Maschal and Truye 2018). For instance, in Addis Ababa, there are a number of pollutant sources that continuously deteriorate the quality of surface and groundwater (Maschal and Truye 2018). About $90 \%$ of industries which are found in Addis Ababa have simply discharged their sewage into nearby water bodies, streams, open land without any form of treatment (Maschal and Truye 2018). 


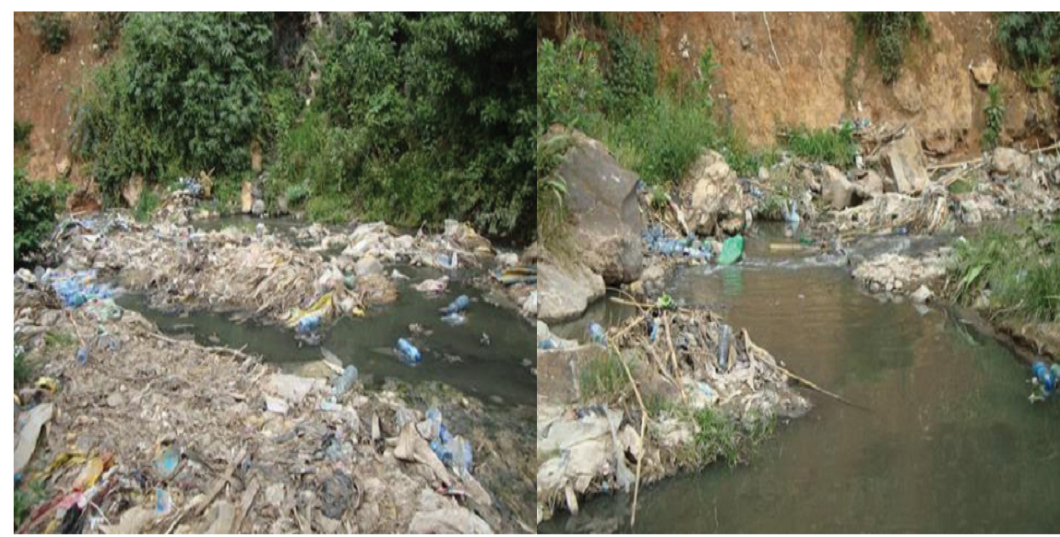

Figure5: Suspended solid wastes on shankila river, Addis Ababa (Maschal and Truye 2018)

\section{Conclusion}

In Ethiopia, the concern of rapid population growth rates is an increasing pressure on natural resources, consequently land degradation. It drives gradually hard to satisfy the basic needs of rising population as the each one intake of resources increases. The amount of population increase will rise the demand of the present which leads to land degradation severity and global insufficiency of land resources for future.

The outcomes of high population growth rates are increasing number of people below poverty line, an increasing population density, and pressure on natural resources. This review paper reveals that the country's population growth is imposing an increasing burden on the country's limited and continually degrading natural resources. So, society should be aware on family planning, natural resource conservation, land resource management and environmental protection to sustain the proportion of population growth of the country with its land resource capacity.

\section{References}

Amara B, Hurni H and Gate Z (2011). Responses of rural households to the impacts of population and land-use changes along the Eastern Escarpment of Wello, Ethiopia.

Bekele S and Holden S (1998). Resource degradation and adoption of land conservation technologies in the Ethiopian Highlands: A case study in Andit Tid, North Shewa. Ethiopia. Agriculture economics. 18:233247.

Bekele S and Stein H(2003). Poverty, Resource Scarcity and Incentives for Soil and Water Conservation: Analysis of Interactions with a Bio-economic Model. International Crops Research Institute for the Semiarid Tropics (ICRISAT) Patancheru 502 324, Andhara Pradesh, India .

Belay T (1995). Population pressure and problems of arable land degradation in Ethiopia: Integration of population, environment equitable and sustainable development issues into the curriculum of the demographic training and research center of the institute of development research at AAU.

Berry L (2003). Land degradation in Ethiopia: its impact and extent in Berry L, Olson J. and Campbell D (end): Assessing the extent, cost and impact of land degradation at the national level: findings and lessons learned from seven pilot case studies. Commissioned by global mechanism with support from the World Bank.

Bezuayehu T, Gezahegn A, Yigezu A, Jabbar M and Paulos D (2002). Nature and causes of land degradation in the Oromiya Region: socio- economic and policy research working paper 36. International Livestock Research Institute.

Breman H and Swift M (1997).Combating nutrient depletion through nutrient replenishment and integrated nutrient management. IFDC Africa, BP 4483, Lome, Togo.

Central Statistical Office (1985). Report on the Results of the 1981 Demographic Survey

Central Statistics Authority(CSA) of Ethiopia, Reports of the 1994 and 2007 Population and Housing Census and the 2012 Inter-censual Survey.

Corbeels M, Abebe S and Mitiku H (2002). Farmers'Knowledge of soil fertility and local management strategies in Tigray, Ethiopia. Managing Africa's Soils No. 10.

Desta L, Menale K, Benin S and Pender J (2000). Land degradation and strategies for sustainable development in the Ethiopian highland, Amhara region: socio-economic and policy research working paper 32. International Livestock Research Institute.

Drechsel P, Gyiele L, Kunze D and Cofie O (2001). Population density, soil nutrient depletion, and economic growth in sub-Saharan Africa. Ecological Economics.38: 251-258.

Fantaw Y (2007). Soil properties in relation to topographic aspects, vegetation communities and land use in the South-eastern Highlands of Ethiopia. Ph.D thesis, Swedish University of Agricultural Sciences. 
FAO (Food and Agriculture Organization), (1986): Highland reclamation study of Ethiopia.

Final Report, Volume 1, Rome

Fitsum H, Pender J and Nega G (1999).Land degradation in the highlands of Tigray and strategies for sustainable land management: Socio economics and Policy Research Working Paper 25. International Livestock Research Institute.

Gebreyesus B and Kirubel M (2009). Estimating Soil Loss Using Universal Soil Loss Equation (USLE) for Soil Conservation planning at Medego Watershed, Northern Ethiopia. Journal of American Science. 5(1):58-69.

George H(2002). Land degradation assessment in dry lands. Land and Plant Nutrition Management Service. Land and Water Development Division. FAO.

Gete Z, Menale K, Pender J and Mahmud Y (2006). Stakeholder analysis for Sustainable Land Management (SLM) in Ethiopia: Assessment of opportunities, strategic constraints, information needs, and knowledge gaps. Environmental Economics Policy Forum for Ethiopia (EEPFE).

GeteZeleke(2002).Resource Use and Poverty in the Ethiopia Highlands. In: TilahunAmede (ed.) proceeding of a conference on Natural Resource Degradation and Environmental Concerns in the Amhara National Regional State: Impact on Food Security.pp 109-125.

Girma T (2001). Land Degradation: A Challenge to Ethiopia. International Livestock Research Institute, Addis Ababa, Ethiopia. Pp 815-823.

Gurmessa F(2015). Forest loss and climate change in Ethiopia. Research Journal of Agriculture and Environmental Management. 4(5): 216-224

Hailu A (2010). The Effect of Compost on Soil Fertility Enhancement and Yield Increment Under Smallholder Farming - A Case of Tahtay Maichew District - Tigray Region, Ethiopia. Ph.D Dissertation, University of Hohenheim Agricultural Sciences

Hurni H, Solomon A, Amare B, Berhanu D, Ludi E, Portner B, Birru Y and Gete Z (2010). Land degradation and sustainable land management in the highlands of Ethiopia. In Hurni H, Wiesmann U (ed) with an international group of co-editors. Global change and sustainable development: A synthesis of regional experiences from research partnerships. Georaphica Bernensia. 5:187-201.

Hussen H(2006). Land Use Change and Challenges of Land Degradation in Adaba Area, Bale Zone, Ethiopia

Lambin E, Geist H and Lepers E (2003). Dynamics of land use and land cover change in tropical regions. Annu. Rev. Environ. Resour. 28: 206-232.

Maschal and Truye (2018). Causes and impacts of Shankila River water pollution in Addis Ababa, Ethiopia. Environ Risk Assess Remediat, 2(4):21-30.

McKee J (2007). "Ethiopia, Country Environmental Profile." Report prepared for the European Commission.

Mitiku H, Herweg K and Stillhardt B (2006). Sustainable Land Management - A New Approach to Soil and Water Conservation in Ethiopia. Mekelle, Ethiopia: Land Resources Management and Environmental Protection Department, Mekelle University; Bern, Switzerland: Centre for Development and Environment(CDE), University of Bern, and Swiss National Centre of Competence in Research (NCCR) North-South. 269 pp.

Mitiku, H., Berhanu, G. and Amare, B. (2003): The status of soil fertility in Tigray. In: Proceeding of the "Policies for Sustainable Land Management in the Highlands of Tigray, Northern Ethiopia." Socioeconomics and Policy Research (Working Paper No. 54) ILRI. 28-29

MOA (2007). The cost of land degradation in Ethiopia: A Review of Past Studies. World Bank in collaboration with the Environmental Economics Policy Forum of Ethiopia and the International Food Policy Research Institute, Addis Ababa.

Muluneh W (2003). Population growth and environmental recovery: more people, more trees; lesson learned from western Gurage land SetarewKenew, WorknehKelbessa, WuduTesfa and DemesieFantaya (ed), Ethiopian Journal of Social Sciences and Humanities. 1(1):1-33.

Munro R, Deckers J, Mitiku H, Grove A, Poesen J and Nyssen J (2008). Soil landscapes, land cover change and erosion features of the Central Plateau region of Tigrai, Ethiopia: Photo-monitoring with an interval

Owa, F (2013). Water Pollution: Sources, Effects, Control and Management. Mediterranean Journal of Social Sciences. 4 ( 8):1-17

Paulos D (2001). Soil and water resources and degradation factors affecting their productivity in the Ethiopian highland agro-ecosystems. Michigan State UniversityPress. 8(1): 1-18.

Teklu W(2016). Rapid population growth and Environmental degradation in Ethiopia: Challenges and Concerns. Pyrex Journal of Ecology and The Natural Environment. 2 (4) : 18-24

Temesgen G, Amare B and Abraham Mahari (2014a). Population dynamics and land use/land cover changes inDera District, Ethiopia. Global Journal of Biology,Agriculture and Health sciences. 3(1):137-140.

Temesgen G, Amare B and Abraham Mahari (2014b). Evaluations of Land Use/Land Cover Changes and Land Degradation in Dera District, Ethiopia: GIS and Remote Sensing Based Analysis. International Journal of Scientific Research in Environmental Sciences. 2(6):199-208. 
Temesgen G (2015). Soil Erosion in Ethiopia: Extent, Conservation Efforts and Issues of Sustainability. Pjpalgo Journal of Agriculture. 2 (2), pp 38-48

Tilahun A, Takele B and Endrias G (2001). Reversingthe degradation of arable land in the Ethiopian highlands. Managing Africa's soils No. 23. International center for research in agro forestry. pp1-20.

USAID CRSPT (USAID Collaborative Research Support Programs Team) (2000). Amhara national regional state food security research assessment report.

Wall J, Baldwin S and Shelton J (2003). "Soil Erosion - Causes and Effects " Factsheet.

World Bank, (2004): World development report 2005. Washington, D.C.: The World Bank. 